\title{
CYP2C19 Gene
}

National Cancer Institute

\section{Source}

National Cancer Institute. CYP2C19 Gene. NCI Thesaurus. Code C26512.

This gene is involved in the metabolism of drugs and xenobiotics. 